\title{
THE USE OF HUMOR STORY IN IMPROVING THE STUDENTS' READING COMPREHENSION
}

\author{
Like Raskova Octaberlina, Andi Asrifan \\ ${ }^{1}$ Universitas Islam Negeri Maulana Malik Ibrahim, Malang, Indonesia \\ ${ }^{2}$ Universitas Muhammadiyah Sidenreng Rappang
}

\begin{abstract}
The goal of the research was to find ways of improving the readability of students and students at SMP Negeri 4 Pancarijang Eight and Humor Tales.

This inquiry used a hybrid approach using monolingual groups. The study population in the academic year 2018-2019 was the 8th grade student. There were 65 students, each class consists of 20-22 students, in 3 classes (VIII.1, VIII.2 and VIII.3). The researcher chose VIII.2, a random and a total of 21 students, as the representative. Two types of tools, namely reading comprehension test and questionnaires, were used to collect research data. The reading test was used to collect data on the reading skills of students and the student preferences in reading understanding through the Humour Tale questionnaire was used.

The data analysis revealed that after they were taught using humor story and before they were taught by humor, there was a substantial difference between the score of students. The mean post-test score, which was above the average pre-test score $(57.57>40.33)$, has been verified. The p-value result $(0,000)$ was also below the mean amount $(\alpha=0.05)$; that is to say, H1 was accepted. Then the Likert Scale study of interest showed that the students were interested in teacing reading understanding with laughter. 57 percent of highly interested students, 33 percent interested and 10 percent intermediate students proved it. The study concluded on the basis of data analyzes: (1) using humor story to enhance student's understanding of reading; and (2) using humor story makes students interested in reading understanding.
\end{abstract}

Keyword: Humor Story and Reading Comprehension

\section{INTRODUCTION}

English in Indonesia consists of four language learning skills, one of which is literacy. The value of reading for someone we need to realize, particularly reading understanding. A tool to study various fields of science is required for reading comprehension. By reading understanding one's talents, abilities and intellect will be developed and also a variety of information will be obtained.
Reading is an incredibly valuable language skill. Understanding reading requires more than an answer from the reader to the text. Comprehension of reading is a highly complex process, involving a great deal of interplay between the reader and what they bring to the text (prior knowledge, strategies) and variables related to the text itself (interest in the text, understanding of text type) (Klingner 2007:8)

The student's interest in reading has not been adequate based on the assertion above on 
the value of reading. Indonesia was just 0.001 percent or the second lowest in the countries surveyed at just one rank above Botswana in Africa, based on a 2012 UNESCO survey on reading interest in 61 countries (kominfo.belitungkab). And the average reading frequency for Indonesians is 3 to 4 times a week according with data from the National Library in 2017. While there are only five to nine books a year that are read in average.

The learning process is known as we know of other factors influencing student understanding. Some teachers still use the method of explaining, explain the material only and students listen only to what they say. Students do not want to learn and their success reduces the outcomes that are dull. You need several activities that can make you happy with the reading process to achieve the main objectives of the study process. In Novia (2016), Adi W. Gunawan says that no singletopic subject is available. Teachers do not know how to provide nice, fun and interesting materials to students. They must be professor.

We may use various approaches to enhance our understanding of reading. One of them uses the tale of humor. The goal is to help students learn how to read and appreciate the process of learning in the classroom. Learn, enjoy having fun. Expert indicates that laughter is an effective instrument for facilitating language learning. Humor is a matter of interest to us. Humor was a part of our pedagogical framework most notably. It gives students inspirational enthusiasm. Teachers mention various moods for teaching English. Sady (2017).

A. Majid Hayati (2011) state Humor, though universal and essentially conveyed through expression, forms a unique part of human experience. In all languages and cultures, this is common. The use of mood therefore provides great advantages for language teachers and students within the framework of second language learning. Practice reading needs, make it fun and enjoyable for students to read, inspire students to read more and teach them to understand. As a result, some other reading materials will be easier for students to understand.

\subsection{The Nature of Reading}

The reading process is carried out to uncertainly reduce the meaning of a text, which transmits the process resulting from meaning negotiation. Then we should mention that reading is awareness, expectation and technique that the reader uses to convey textual significance and that they all have decisive roles in negotiating the significance of the text.

Reading means to grasp the significance of written words or symbols according to Patel and Jain (2008). Reading is an involved method of understanding and comprehension. Reading is important activities in life, such as people are able to update or acquire knowledge.

Kozak M (2011) defines the reading as an ability to get a word, to recognize written word(signs), to understand meaning, to teach pronunciation and to receive information from the text. It is also used to understand the meaning.

In longman Dictionary of Applied Linguistic, reading as:

a. The process of meaning from written text understanding. When this do secretly it is know as silent reading

b. Saying written text aloud (reading aloud). This can be done by understanding of the content or not. 
Based on the above definition, reading is important in everyday life, and also reading is not only the process of getting written symbols in accordance with one's oral language but also the process of getting the message to be conveyed by the author.

\subsection{Types of Reading}

There are the following types of reading according to Patel and Jain (2008: 117-123)

a. Intensive reading

Intensive reading is an activity that is carried out carefully and thoroughly on the text that is read. reading will provide a basis for explaining structural difficulties and for expanding vocabulary and idiom knowledge. This will also provide material for developing greater language control in speech and writing. Intensive reading is reading a text or reading a part. In reading this students read the text to get knowledge or analysis. The purpose of this reading is to read shorter texts. This reading is done to get specific information. Students read books to gain knowledge.

\section{b. Extensive Reading}

Extensive reading is a technique used to get a general understanding of a subject and includes reading longer discourse texts for pleasure. Readers are curious about something. Readers do not care about specific or important information after reading. Usually people read so that they keep updating.

\section{c. Aloud Reading}

Aloud reading is basic form of classroom disciplines and organization. In reading aloud, the students are confronted with written sentences that haven never been spoken before. The purpose of reading aloud is an ability or achievement of better speaking and pronunciation of students.

\section{d. Silent Reading}

Silent reading is a silent reading technique which is a very important skill in teaching English. This reading is usually used to increase reading skills among students. Silent reading is done to get a lot of information. The teacher must make them read calmly and when they can read without difficulty. This is a kind of habit where students can read without sound that can interfere with reading.

\subsection{Technique of Reading skill}

Brown (2001:308) states that in English language there are three kinds of reading technique, they are:

a. SurveyReading

In survey reading, a reading survey some informations that they want to get.Thus before that reading process a reader must be set what kind of information the reader needs.

\section{b. Scanning}

In scanning reading, the reader quickly to answer a specific question quickly. When scanning the reader only try to locate specific information and they do not follow the linearuty of the passage to do.

\section{c. Skimming}

Skimming is a kind of reading that makes our eyes moves quickly it used to quickly identify the main ideas of a text, to look at section heading, summaries and opening paragraphs.

\subsection{Definition of Reading Comprehension}

Reading comprehension is the ability to process text, understand the meaning of the text and integrate it with what the reader knows. The ability of individuals to understand text is influenced by their skills and their ability to process information. 
Understanding reading is the ability to process, understand and integrate text with what the reader knows. The ability to understand and influence your information management skills. Learning is a multicomponent, complex process involving many interactions between the reader and what the readers provide (enforceable knowledge, use of strategies) and the variables of the text (interest in texts, type of text understanding) (2007:8)

Learning understanding is a means of understanding meaning and of integrating with what the reader knows. Knowledge of the meaning of the words, the ability to understand the meaning of the words from the discourse context, the ability to identify their references, the ability to draw conclusions from the contents of a part, the ability to identify one of the major thoughts of a part, the ability to answer questions answered in the following section, and the ability to recover

The researcher concludes from the above definition that the understanding of the reading is the capacity to understand the reading through the understanding, meaning, definition, organization, evaluation, etc., and also to know the contents or meaning of the reading the authors want to communicate.

\subsection{Strategies for reading comprehension}

The process of understanding text begins before children can read when someone reads a picture book to them. They listen to the words, look at the pictures in the book, and start associating the words on the page with the words they hear and the ideas they represent.

To learn strategies for understanding, students need modeling, practice, and feedback. Strategies taught are explained below.Read Naturally (2018)

1) Using Previous Knowledge / Preview
When students preview the text, they use what they already know that will help them understand the text they are about to read. This provides a framework for every new information they read.

2) Predict

When students make predictions about the text they are about to read, it sets expectations based on their prior knowledge of the same topic. When they read, they may mentally revise their predictions because they get more information.

3) Identifying the Main Idea and Summarizing

Identifying key ideas and summarizing requires students to determine what is important and then put it in their own words. Implicit in this process is trying to understand the purpose conveyed by the author's in writing text.

4) Questioning

Submitting and answering questions about text is another strategy that helps students focus on the meaning of the text. The teacher can help by modeling both the process of asking questions and good strategies for finding answers in the text.

\section{5) Make Conclusions}

To make conclusions about something that is not directly stated in the text, students must learn to draw on previous knowledge and recognize clues in the text itself.

\section{6) Visualize}

students who visualize while reading have better memories than those who don't. Readers can use illustrations embedded in text or create their own images or mental images when reading text without illustrations.

From the definition above, reading comprehension refers to an understanding of what has been read. Understanding is a process of thinking that depends not only on 
understanding skills but also on the background of readers' knowledge and experience.

\subsection{Teaching Reading Comprehension}

In teaching reading comprehension, teachers need strategies to make students understand the reading text. According to Brown (2001: 306-311), the following are strategies that can be applied in teaching reading comprehension:

1) Identifying the purpose in reading

By knowing the purpose of what the reader is reading, the reader can eliminate where unwanted interference or information. With this strategy, students will get information what they want to know in reading the text.

2) Using graphemic rules and patterns to aid in bottom up decoding (especially for the beginning level learners)

Learning English at the initial level faced is one of the difficulties of students in learning to read is to make correspondence between spoken and written English. Here teacher also need to teach how to read the sound words with sort vowel sound such as (bat, leg, wish, etc) and the sound words with final silent "e" such as (late, time, bite, etc).

3) Using efficient silent reading techniques for relatively rapid comprehension (for intermediate to advanced levels)

In advanced learner, teacher can apply reading fast to reduce time consuming in reading. Readers do not need to pronounce every word and do not need to know the meaning of every word but the comprehension of the text is more important.

4) Skimming the text for the main ideas

Skimming is one of the most important reading strategies for students. Skimming is a quick reading technique to look for important things and main reading ideas (such as essays, articles, or chapters) to find out about the contents of the text or to find out the main ideas of the text. Skimming gives readers the advantage of being able to know the purpose of this passage, the main topic, or massage, and maybe some ideas that develops or support

5) Scanning the text for specific information

Scanning is a reading technique that quickly searches for certain information that the reader needs to read the text. Scanning exercises can ask students to look for names or dates, to find key concept definitions, or to list a number of supporting details

6) Using semantic mapping or clustering

The reader can summarize the long series of ideas or events by grouping keywords from the words they get from the reading. Semantic mapping strategies, or group ideas into meaningful groups, help readers to remember the contents of the text.

7) Guessing when you are not certain

Brown states that guessing is a very broad category. Learners can use guessing to their advantage to:

a) guess the meaning of the word,

b) guess the grammar relationship (eg, pronoun reference)

c) guess the discourse relationship,

d) concluding the implicit meaning ("between lines"),

e) guess about cultural references, and

f) guess massage content,

These micro skills can be used for teachers as a strategy to overcome difficulties in students' reading comprehension. In addition, students must encourage themselves to become strong readers. Strong reading skills help students in all other subjects and in their personal and professional lives in the future. 


\subsection{The Concept of Humor}

Humor is a unique, though universal part of human experience and is fundamentally manifested and expressed through language. It is prevalent in all languages and cultures.According to Oxford Advanced Learner's Dictionary 9th edition (2016), humor is the quality in something that makes it funny or amusing; the ability to laugh at things that are amusing. Reddy (2016:9) Humor can create strong bonds and vital elements for connection. When the audience laughs, it means more than being entertained, they laughter says that they understand you, they like you.

Based on that statement humor is a broad term that refers to whatever people like or do that is called funny and contributes to making others laugh, like clothing mental processes that enter into creating and perceiving such funny stimuli, and also affective responses involved in enjoy that.

\subsection{Component of humor}

In terms of psychological perspectives, the humor process can be divided into four important components: (1) social context, (2) cognitive-perceptual processes, (3) emotional responses, and (4) expressions of laughter of vocal-behavioral behavior. Martin (2007: 5)

a. Kinds of Humor

Setiawan in Situmeang (2018) categorized humor according to its expression from he state the kind of humor in the following:

1) Performing comedy is delivering a comedy or humor directly through a story or gesture. Such as jest, pantomime, etc, graphic humor such as caricature funny picture etc.
2) Literature humor such as anecdote, funny story humor stories, etc.

b. The Reasons of using humor in classroom Humor is a short narative text of an intresting or amusing it can make students to motivate in reading, because it is intresting and enjoyble for students. The reason of the humor use in classroom there are three widely know and long-standing theory (Moreall 1983):

1. Sociological Benefits

Humor can help establish relationships or be used to strengthen relationships a teacher and student in the class includes attracting students' attention, in order to stimulate class participation. Comfortable interaction can produce students' desire to interact in class activities and this is a good way to improve their language learning. In general, humor, if used properly, can be effective tool for socialization to create and enhance interpersonal relationships.

2. Instructional Benefits (The Incogruity Theory)

Instructional humor that gives rise to positive emotions can be associated with learning. Especially when humor is used and related to subject matter, it can improve language learning and make course content retentive Wanzer,in Algafar (2017). making, students gain more positive attitudes towards education, which then impacts on increasing their student motivation and results in an increase in academic value. This means that the humor used in teaching has an advantage at the intellectual level that can make students produce stimuli to learn lessonsfaster, more active, and interested. This stimulus generated by humor can solve problems related to students' thinking skills.

3. The Reasons of the Humor Avtoidance in Classroom 
Although there are so many good reasons for using humor, there are also several reasons for avoiding humor that teachers need to consider. Wanzer in Algafar (2017) states some examples of humor that should be avoided in classrooms such as making fun of students, stereotypical humor, failing humor, sexual humor, vowing to be funny, joking about serious problems, and personal humor. Humor that leads to certain groups and is based on stereotypes should not be used in the classroom. In addition, there is also humor that fails, when students find that teacher humor is not funny. One reason might be the difference between interpretation of humor based on age, culture, gender, or life experience.

\section{RESEARCH METHOD}

\subsection{Research Design}

This research will apply mixed method design. Mixed method research design combine quantitative and qualitative by sentially mixing both qualitative and quantitative in a research (Gay et al .2006:490).

According to Creswell (2014:268) deviced the mixed methods into three basic:

\section{Convergent Parallel Mixed Methods Design}

In this approach a researcher collects both quantitative and qualitative data, analyzes them separately, and then compares the result to see if the findings confirm or disconfirm each other.

\section{Explanatory Sequential Mixed Methods Design}

The explanatory sequential mixed method disign is an approach that involves a two-phase project in which the researcher collects quantitative data in the first stage, analyzes the results, and then uses the results to plan (or build into) the second qualitative phase. The overall purpose of this design is for qualitative data to help explain further detailed initial quantitative results. A typical procedure might involve collecting survey data at the first phase, analyze the data, and then follow up with qualitative interviews to help explain survey response.

3. Exploratory Sequential Mixed Methods design

An explorative sequential mix method is a design in which researchers first start by exploring qualitative data and analysis and then use the findings in the second quantitative phase. Like the explanatory sequential approach, the second database is based on the results from the initial database. The aim of this strategy is to develop better measurements with specific population samples and to see whether data from several individuals (in the qualitative phase) can be generalized to large population samples (in the quantitative phase).

Based on stated, the resercher are interest to use Convergent Parallel Mixed Methods Design models in this research

\subsection{Variables of the Research and Operation Definition of Variable}

1. Variable of research

This research uses two variable. They are independent variable and dependent variable. The independent variable of this research is the use of humor story $(\mathrm{X})$ and 
dependent vtariable is students, reading comprehension (Y1) and students' interest (Y2).

2. Operational Definition of the variabels

In this section, the researcher explain operational definition of variabels that have mentioned above in the variabel of the research:

a. Reading comprehension is the ability of students to comprehend a reading passage in the form of the text (Spoof Teks)

b. Humor is the quality that can make something seems funny thats make students to motivate in reading, that consists of aspect social context and cognitive-perceptual processes.

c. Students' interest is students' respond after giving treatment for four time.

\subsection{Population and Sample}

1. Population

According to Creswell (2005:142), population is the group of individuals who have the same characteristics. The population of this research is taken from the Eigth Grade students of SMP Negeri 4 Pancarijang in 2018/2019 academic year. The classes are classified based on the students' registration number when they register to enter the school. VIII.1 consist of 22 students, VIII.2 consist of 21 Students and VIII. 3 consist of 22 Students. The number of population was 65 students.
Table 1. The Population Eight-Grade

SMP Negeri 4 Pancarijang

\begin{tabular}{lll}
\hline No. & Class & Students \\
\hline 1 & VIII.1 & 22 \\
2 & VIII.2 & 21 \\
3 & VIII.3 & 22 \\
& TOTAL & 65 \\
\hline
\end{tabular}

Source:Data SMP Negeri 4 Pancarijang

Tahun 2019

2. Sample

Sample is a subgrup of the target population that the resercher plans to study for generalizing about the target population Creswell (2012:142). In this research, the researcher will apply cluster random sampling technique that one class would be the sample. The researcher choose VIII.2 students as the sample the number of total sample are 21 students.

Table 2. Sample Eigth-Grade SMP Negeri 4 Pancarijang

\begin{tabular}{llll}
\hline CLAS & MAL & FEMA & NUMBER \\
S & E & LE & OF \\
& & & STUDEN \\
& & & TS \\
\hline VIII.2 & 11 & 10 & 21 \\
Total Sample & & 21 \\
\hline
\end{tabular}

\subsection{Instrument of the Research}

1. Reading Comprehension Test The research would be using a reading test at the instrument to collect the data used multiple choiche and true false test. The students would be asked to read a text. This test would be administered to the 
students twice namely pre-test and posttest. The post-test would be giving before the treatmnet to get students' prior knowledge in reading. The post-test would be conducted to find out students' reading comprehension after treatment is give (using humor story).

\section{Questionnaire}

The questionnaire distribute to the students after giving treatment, to find out the students interest in learning reading comprehension using "Humor Story". The questioner consisted of 20 items, 10 items positive statements and 10 items negative statements. The research give optional those are: (1) Strongly agree, (2) Agree, (3) Undecided, (4) Disagree, (5) Strong disagree. The questioner would be distributed to the students after the treatment is given.

\subsection{Procedure of Collecting Data}

This data of students and the procedure in collecting data was presented in the chronological order as follows:

1. Pre-test

Before the conducting the treatment, this research administrered the pre-test to identifying students' reading comprehension.

2. Treatment

After conducting the pre-test at the first meeting, the students would be treated by giving humor story.

3. Post-test

After doing treatment, the students gave post-test to find out students' development in building up their reading comprehension by using humor story.

4. Questionnaire

Questionnaire was distributed to the students' to know their interest in learning reading comprehension by using humor story. The quetionnaire consisted of 20 items. Those are 10 positive and 10 negative statement in the questionnaire.

\subsection{Treatment}

The researcher gave the treatment to the students. The treatment would prepare in four meeting. Each meeting, researchers presented material about the humor stories with a different theme each meeting. The procedure of the treatment is follow:

a. Giving motivation.

b. The researcher explain how to learn process would going on.

c. The researcher prepares the material.

d. Giving some some times (5-8 secounds) to ask unclear material.

e. The researcher invites the topic.

f. Provides additional information for students to answer.

After all the process, the researcher gave the students comprehension about the activity and ask their suggestion and commentary about the learning process so that each meeting can be more effective and fun between the reasearcher and students.

\section{RESULT AND DISCUSSION}




\subsection{Result}

3.1.1 The rate percentage score of pre-test and post-test.

The finding were obtained through the test which was conducted through two itms, namely pre-test and post-test

Table 3. The Classification of Students' Score Pre-test and Post-Test

\begin{tabular}{cccccc}
\hline \multirow{2}{*}{$\begin{array}{c}\text { Classificatio } \\
\text { n }\end{array}$} & Scor & & \multicolumn{2}{c}{ Pre-test } & \multicolumn{2}{c}{$\begin{array}{c}\text { Post- } \\
\text { test }\end{array}$} \\
\cline { 3 - 6 } & $\mathbf{e}$ & & & & \\
& & F & \% & F & $\%$ \\
\hline Very Good & $86-$ & 0 & 0 & 0 & 0 \\
& 100 & & & & \\
Good & $71-$ & 0 & 0 & 5 & 24 \\
& 85 & & & & \\
Average & $56-$ & 0 & 0 & 7 & 33 \\
& 70 & & & & \\
Poor & $41-$ & 1 & 62 & 5 & 24 \\
& 55 & 3 & & & \\
Very Poor & $0-40$ & 8 & 38 & 4 & 19 \\
\hline Total & & 2 & 10 & 2 & 10 \\
& & 1 & 0 & 1 & 0 \\
\hline
\end{tabular}

Based on the table above, it explained that most of the students in the pre-test got poor and very poor classification, there are: 13 (62\%) students categorized in poor and 8 $(36, \%)$ students categorized in very poor. But in the post-test they got good classification, 4 (19\%) students categorized in very poor, 5 (24\%) students categorized in poor, 7 (33\%) students categorized in average and 5 (24\%) students categorized in very good. The result of the pre-test was not suitable with what the researcher expected but in the post-test the researcher had seen an increasing. In indicated that the students' achievement increased after being taught using Humor Story.

Table 4. The mean score and standard deviation of pre-test

\begin{tabular}{llcc}
\hline no & Variable & $\begin{array}{r}\text { Mean } \\
\text { Score }\end{array}$ & $\begin{array}{c}\text { Standard } \\
\text { Deviation }\end{array}$ \\
\hline 1 & Pre test & 40.33 & 8.51 \\
\hline 2 & Post test & 57.57 & 14.98 \\
\hline
\end{tabular}

Table 4 shows that the mean score of the students in post-test (57.57) was greater than pre-test (40.33), it means that the students who was teach by using Humor Story was improved

\subsubsection{Hypothesis testing}

In testing hypothesis, the researcher used P-Value formula. In this case, the researcher used t-test formula (paired sample test). The level of significant is a set at $\alpha=0.05$

Table 5. The T-test Value of The Students'

\begin{tabular}{ccc}
\multicolumn{3}{c}{ Reading Comprehension } \\
\hline P-Value & $(\mathbf{a})$ & Remarks \\
\hline 0.000 & 0.5 & $\begin{array}{c}\text { Significant } \\
\text { difference }\end{array}$ \\
\hline
\end{tabular}

Based on the students result obtained and stated in findings above, the researcher used paired samples t-test in inferential statistic through SPSS 21.0 program for Windows Evaluation Version to test the hypothesis. In pre-test and post-test, the researcher found that the $p$-value was lower than the $\alpha(0,000<0,05)$. This means that $\mathrm{H}_{0}$ was rejected and $\mathrm{H}_{1}$ accepted. It means that teaching reading comprehension through English learning material design using Humor Story has the good to the students.

\subsubsection{The Students' Interest}


To know the students' interest toward the use of Humor Story in improving students' reading compreension, the researcher distributed questionnaire to the students. The data was analyzed by using Likert Scale and SPSS. These results can be seen on table 6

Table 6. The Rate Percentage of Students'

\begin{tabular}{lccr}
\multicolumn{5}{c}{ Interest } \\
\hline Category & $\begin{array}{c}\text { Interv } \\
\text { al } \\
\text { Score }\end{array}$ & $\begin{array}{c}\text { Frequen } \\
\text { cy }\end{array}$ & $\begin{array}{c}\text { Percenta } \\
\text { ge }\end{array}$ \\
\hline Strongly & $85-$ & 12 & 57 \\
Interested & 100 & 7 & 33 \\
Interested & $69-$ & & \\
Moderate & $54-$ & 2 & 10 \\
Uninteres & $36-$ & 0 & 0 \\
ted & 51 & & \\
Strongly & $20-$ & 0 & 0 \\
Uninteres & 35 & & \\
ted & & & \\
\hline \multicolumn{4}{c}{ Total } \\
\hline
\end{tabular}

Based on the percentage analysis of students' interest on the table 6 above, The analysis indicated that the students were strongly interested to improve the reading comprehension through English learning material Humor Story. It was proved by interest mean $(84,57)$ where $57 \%$ students were strongly interested, $33 \%$ students were interested, and $10 \%$ students were moderate.

Table 7. The Mean Score of Students' Interest

\begin{tabular}{ccc}
\hline $\begin{array}{c}\text { Total } \\
\text { Respondent }\end{array}$ & $\begin{array}{c}\text { Total of } \\
\text { Students' Score }\end{array}$ & $\begin{array}{c}\text { Mean } \\
\text { Score }\end{array}$ \\
\hline 21 & 1776 & 84.57 \\
\hline
\end{tabular}

The table 7 shows that the mean score of students' interest was 84.57 which was categorized as strongly interested. Then, it can be concluded that the application of Humor Story in reading comprehension is interesting.

\subsection{Discussion}

The section of discussion addresses the conclusions, some hypotheses and the interpretation of the test results of both classes, derived from descriptive and inferential statistics.

The explanation of the information gathered during the evaluation, as described in the last segment, indicates that after therapy the understanding of reading by using Humor Story has been enhanced. The average score of the student evaluation in post-test students was sponsored. The average after-test score was 40.33. Data in the previous section showed that using humor story improves student understanding. The difference between the average post-test scoring (57.57) and the pretest is supported by the (40.33).

The researcher used a t-test of the inferential statistic via SPSS version 21.0 to test the hypothesis, based on the results obtained and recorded in the above findings. In test results, the value $\mathrm{p}$ is less than alpha $(0.000<0.5)$ as seen in the statistical test results. This means $\mathrm{H} 1$ has been approved and $\mathrm{HO}$ has been denied. There was a substantial gap in reading understanding between students. In other words, after applying the humor story in SMPN 4 Pancarijang, the understanding of reading was strengthened by the students.

On the other hand, the researcher also found that students who were involved had been using humor to enhance their 
understanding of reading. The average score of 84,57 was sponsored and categorized into an interested group.

In terms of the above explanation, the scientist also found that the highest reading understanding score. The use of humor story was also good for better understanding reading. In support of this statement, Hamka (2001) says that humor can work to achieve every intention and every goal, humor can make someone see trouble on any different sides, humor can entertain, humor can quickly make someone smart, humor can make someone tolerate something and humor can also help somebody understand complex issues. He says: Hamka (2001). And at the other Algafar (2017), students have a more positive approach to education, which then has an impact on the motivation of students and on academic value. The humor used in teaching therefore has an intellectual advantage, which can encourage students to learn more quickly, actively and interestingly.

Based on the students result obtain and stated in findings above, the research use pvalue in inferential statistic through SPSS version 21.0 program to test the hypothesis. In the other words, there was an improvement on the students' reading comprehension after used humor story at SMP Negeri 4 PancaRijang.

\section{CONCLUSIONS}

Based on the result of data analysis and the discussion of the result in the previous chapter, the researcher has concluded as the following:

The use of Humor Story is effective to improve the students' reading comprehension students of Eigth Grade of SMP Negeri 4 Pancarijang. It was proved by the mean score $(40.33<57.57)$ and hypothesis testing showed p-value was lower than alpha (a) value $(0.000<0.005)$, it means that null hypothesis (H0) was rejected and alternative hypothesis was accepted.

Based on the findings, the analysis shows that the use of Humor Story influenced significantly students' interest in learning English. This means that using Humor Story is a good applicable strategy in teaching reading comprehension. Based on the percentage analysis of students' interest in this research, the analysis showed that $57 \%$ who were strongly interested, $33 \%$ who were interested and $10 \%$ who were Moderate. This means Humor Story is a good applicable strategy in teaching reading comprehension.

\section{REFERENCES}

Algafar, Riri. 2017. Teachers' Perspectives toward the Use of Humor in Teaching English as a Foreign Language. (online)

http://repository.una.ac.id/1646/1/A1 B213022-ARTIKEL.pdf Access 26 Desember 2018)

Brown, H Douglas. 2001.Strategies for success: A practical guide to learning english. New york: A Person Education.

Brown, H. Douglas. 2001. Teaching by Principles: An Interactivte Approach to Language Pedagogy 2nd edition. California: Longman

Creswell. 2014. Educational research : planning, conducting, and evaluating quantitative and qualitative research 4th edition. Pearson

Day, Richard R \& Jeong-suk, Park. Developing reading comprehension questions. Volume 17, No. 1, April 2005 ISSN 1539-0578 
Gay, L.R.,Milla, Geoffrey., and Airasian, Peter. 2006. Education Research Competencies for Analysis and Applicationj 8th edition. Ohio:Pearson Prentice Hall

Klingner, Janette K., Vaughn, Sharon. \& Boardman, Alison. 2007. Teaching Reading Comprehension to Students with Learning Difficulties. London: The Guilford Press.

M, Kozak. 2011. The types of Reading and Exercises for Teaching Reading. (online) http://www.eosnova.ru/PDF/osnova_10_0_696.pd f Access 26 December 2018)

Martin, Rod A. 2007. The Psychology of Humor: An Integrative Approach. Elsevier Inc. All

Oxford Advanced Learner's Dictionary 9th edition. Oxford University Press 2016. Application version 1.0.12.0 Patel, M.F. and Jain, Praveen M. 2008. English Language Teaching (methods, Tool and Techniques). Jaipur: Sunrise Publishers \& Distributors

Pratiwi, Priska Sari. 2018. Minat Baca Indonesia Masih Rendah. CNN Indonesia.

https://www.cnnindonesia.com/gayahidup/20180326160959-282285982/minat-baca-masyarakatindonesia-masih-rendah, Access 30 November 2018

rReddy, ramakrishna. 2016. Connect Using Humor and Story How I Got 18 Laughs 3 Applauses in a 7 Minute Persuasive Speech.

PublicSpeakKing.com

Richards, Jack C. \& Schmidt, Richard. 2010. Longman Dictionary of Language Teaching and Applied Linguistics-4th edition. Britain: Pearson Education Limited.

Situmeang, Lamhot Martua. 2018. Improving Students' Reading Comprehension Through Humor Stories at SMP Negeri 5 Sibolga. Vol. 1, No. 1, August 2018.

Asrifan, A. (2009). Using songs in teaching English language for the young learners. ParePare: unpublished.

Puasa, K., Asrifan, A., \& Chen, Y. (2017). Classroom Talk in Bilingual Class Interaction. Research in Pedagogy, 7(1), 106-121.

Nadirah, N., Tahir, M. H., \& Asrifan, A. (2019). THE ABILITY TO TRANSLATE ENGLISH PHRASES INTO INDONESIAN AND THE DIFFICULTIES FACED BY THE ELEVENTH GRADE STUDENTS OF SMAN 1 PANCARIJANG. JOURNAL OF ADVANCED ENGLISH STUDIES, 2(1), 41-46.

Apdy, A. P. R., \& Asrifan, A. (2019, April). The Chinese mime game in teaching vocabulary on EFL classroom. In PROCEEDINGS OF THE 65th TEFLIN INTERNATIONAL CONFERENCE (Vol. 65, No. 01).

Taslim, T., Asrifan, A., Chen, Y., \& Nurdania, N. R. (2019). CORRELATION BETWEEN STUDENT'S VOCABULARY MASTERY AND SPEAKING SKILL. JOURNAL OF ADVANCED ENGLISH STUDIES, 2(2), 65-76.

Muthmainnah, M., Asrifan, A., Al Yakin, A., \& Sahabuddin, C. (2019, April). The use of dictogloss technique on ELT classroom: An experiment study of students listening comprehension.

In PROCEEDINGS OF THE 65th 
TEFLIN INTERNATIONAL CONFERENCE (Vol. 65, No. 01).

Mutmainnah, M., Azis, S., Maulidya, U., \& Asrifan, A. (2017). Glory Style in Mandar Song Lyrics: A study of Mandar Tribe in South Sulawesi, Indonesia. JOURNAL OF ADVANCES IN LINGUISTICS, 8(1), 1286-1291.

Asrifan, A., Rinantanti, Y., Tang, S., \& Nadirah, N. (2019). THE 3DIMENSION PICTURES IN INCREASING THE STUDENTS ABILITY AND INTEREST TO WRITE DESCRIPTIVE COMPOSITION. JOURNAL OF ADVANCED ENGLISH STUDIES, 2(1), 19-30.

Asrifan, A., Nadira, N., \& Haedar, H. (2018). IMPROVING STUDENTS'READING COMPREHENSION $\quad$ OF THROUGH COLLABORATIVE MURDER. JOURNAL OF ADVANCED ENGLISH STUDIES, 1(2), 21-31.

Asrifan, A. (2015). Analysis of English Students' Learning Style in Bilingual Class. International Journal of Literature and Arts, 3(4), 34.

Farahdiba, S., \& Asrifan, A. (2016). Speaking Ability and Psychological Barriers of the Second Year Students of Hotel Department of SMKN 1 Sidenreng Kabupaten Sidrap in Speaking English. Asian EFL Journal, (89), 41.

Asrifan, A. (2012). Increasing the Students Ability to Write Descriptive Composition at SMP Negeri 13 Parepare by using the 3-Dimension Pictures.

Tang, S., Asrifan, A., Chen, Y., Haedar, H., \& Agussalim, M. (2019). THE HUMOR STORY IN TEACHING READING COMPREHENSION. JOURNAL
OF ADVANCED ENGLISH STUDIES, 2(2), 77-87.

Nurwanti, N., Asrifan, A., \& Haedar, H. (2019). THE APPLICATION OF COOPERATIVE LEARNING: JIGSAW II TECHNIQUE IN IMPROVING STUDENTS'READING COMPREHENSION OF EXPOSITORY TEXT. JOURNAL OF ADVANCED ENGLISH STUDIES, 2(1), 31-40.

Asrifan, A. (2016). The Effectiveness of Think-Pair-Share Technique in Improving Studentsâ€ $€^{\text {TM }}$ Speaking Ability and Interest. English Literature and Language Review, 2(3), 24-35.

Asrifan, A., Muthmainnah, M., Al-Yakin, A., Sahabuddin, C., \& Haedar, H. (2018). THE CAUSE-EFFECT TECHNIQUE IN TEACHING RECOUNT

WRITING. JOURNAL OF ADVANCED ENGLISH STUDIES, 1(2), 63-72.

Asrifan, A., Vargheese, K. J., Syamsu, T., \& Amir, M. (2020). ESP COURSE DESIGN: THE NEED ANALYSIS ON TOURISM DEPARTMENT IN INDONESIA VOCATIONAL HIGH SCHOOLS. JOURNAL OF ADVANCED ENGLISH STUDIES, 3(2), 69-77.

Asrifan, A., Ghofur, A., \& Azizah, N. (2020). Cheating Behavior in EFL Classroom (A Case Study at Elementary School in Sidenreng Rappang Regency). OKARA: Jurnal Bahasa dan Sastra, 14(2), 279-297.

Nadirah, N., Asrifan, A., Vargheese, K. J., \& Haedar, H. (2020). INTERACTIVE MULTIMEDIA IN EFL CLASSROOM: A STUDY OF TEACHING READING COMPREHENSION 
AT JUNIOR HIGH SCHOOL IN INDONESIA. JOURNAL OF ADVANCED ENGLISH STUDIES, 3(2), 131-145.

Muthmainnah, A. R., Atmowardoyo, H., Salija, K., \& Asrifan, A. (2020). Literary Work as Teaching Materials: A Study of Students and Lecturers Needs Analysis. Solid State Technology, 63(5), 394-407.

Tilome, A. A., Agustang, A., Jasruddin, M. S., \& Asrifan, A. (2020). Social Exchange of Political Elites in the Regional Leader Election of Gorontalo Province, Indonesia. Solid State Technology, 63(5), 521-531.

Pacinongi, A., \& Asrifan, A. (2020). Bimbingan Pengawas Berkelanjutan dalam Mewujudkan Pendidikan Karakter Bangsa dalam Kegiatan Belajar Mengajar Penjaskes. Celebes Education Review, 2(1), 1-7.

Gunawan, G., \& Asrifan, A. (2020). Penerapan Kerja Kelompok Kegiatan MGMP Guru Ekonomi dalam Menyusun RPP untuk Meningkatkan Kompetensi Pedagogik. Celebes Education Review, 2(1), 31-36.

Yusuf, I., \& Asrifan, A. PENINGKATAN

AKTIVITAS KOLABORASI PEMBELAJARAN FISIKA MELALUI PENDEKATAN STEM DENGAN PURWARUPA PADA SISWA KELAS XI IPA SMAN 5 YOGYAKARTA. Editorial Team, 32.

Al Yakin, A., Sahabuddin, C., Rahayu, A., Fitrah, N., \& Arifin, M. (2020). Political Celebrification and Electability: A Study of Political Phenomena Imaging in Election Polewali Mandar District, West Sulawesi, Indonesia. Solid State Technology, 63(5), 632-646.
Junaedah, S. B. T., \& Ahmad, M. A. (2020). The Outdoor Learning Modules Based on Traditional Games in Improving Prosocial Behaviour of Early Childhood. International Education Studies, 13(10).

Octaberlina, L. R., \& Muslimin, A. I. (2020). Efl students perspective towards online learning barriers and alternatives using moodle/google classroom during covid-19 pandemic. International Journal of Higher Education, 9(6), 1-9.

Octaberlina, L. R., \& Anggarini, I. F. (2020). Teaching vocabulary through picture cards in Islamic Elementary School: a case study in Nida Suksa School, Thailand. Jurnal Madrasah, 13(1), 26-38.

Octaberlina, L. R. (2016). Plagiarism in English language theses in Indonesia. Jurnal Ilmu Pendidikan, 14(3).

Octaberlina, L. R., \& Anggarini, I. F. (2020). Teaching vocabulary through picture cards in Islamic Elementary School: a case study in Nida Suksa School, Thailand. Jurnal Madrasah, 13(1), 26-38.

Octaberlina, L. R., Anggarini, I. F., \& Muslimin, A. I. (2020). Virtual English teaching in remote area: a case study. Journal of Critical Reviews, 7(19), 9707-9713.

Amalia, L. L. (2019). REFLECTIVE PRACTICE AND SELFIDENTITY AS PARTS OF PROFESSIONAL DEVELOPMENT: A SURVEY IN A TERTIARY LEVEL. E-Link Journal, 6(1), 160-163.

Asrifan, A., Zita, C. T., Vargheese, K. J., Syamsu, T., \& Amir, M. (2020). THE EFFECTS OF CALL (COMPUTER ASSISTED LANGUAGE LEARNING) TOWARD THE 
STUDENTS'ENGLISH

ACHIEVEMENT

AND

ATTITUDE. JOURNAL OF ADVANCED ENGLISH

STUDIES, 3(2), 94-106.

Asrifan, A. (2021). ACADEMIC WRITING. LawArXiv.

January, 2.

https://doi.org/10.31228/osf.io/x2s $7 \mathrm{e}$

Asrifan, A. (2020). TUTORIAL PENGGUNAAN QUIZIZZ (www. quizizz. com) PADA PEMBELAJARAN. https://doi.org/10.31219/osf.io/kq

nza

Asrifan, A. (2021). Abd Ghofur.“. THE USE OF READING CIRCLES IN INCREASING STUDENTS SPEAKING ABILITY AT THE ELEVENTH GRADE SMK NEGERI, 1.

https://doi.org/10.31219/osf.io/8vj xy

Asrifan, A. (2020). Pandemic, Humanity and Education.

https://doi.org/10.31219/osf.io/q2 gpk

Asrifan, A. (2021). USING CAT AND MOUSE GAME TO IMPROVE STUDENT'S SPEAKING ABILITY AT THE ELEVENTH GRADE OF MA YMPI RAPPANG.

https://doi.org/10.31219/osf.io/pht vn

Asrifan, A., \& Ghofur, A. (2021). THE USE OF READING CIRCLES IN INCREASING STUDENTS SPEAKING ABILITY AT THE
ELEVENTH GRADE SMK NEGERI 1 PANCARIJANG. https://doi.org/10.31219/osf.io/8vj $\mathrm{xy}$

Asrifan, A. (2021). Book Review: Halliday. 1989. Spoken and Written Language. Oxford University Press.

https://doi.org/10.31219/osf.io/ej8 tb

Asrifan, A., \& Ghofur, A. (2021). TALK, ACTION, SILENCE, INTERRUPTION AND THEIR IMPLICATIONS IN BUGINESE SOCIETY (SOPPENG REGENCY).

https://doi.org/10.31219/osf.io/pv $3 \mathrm{ku}$

Asrifan, A. (2020). PENILAIAN BERBASIS ANDROID MENGGUNAKAN APLIKASI PLICKERS https://doi.org/10.31219/osf.io/htr eq

Asrifan, Andi, Octaberlina, L. R., \& Agus, Selviana. (2021, January 8). IMPROVING STUDENTS SPEAKING ABILITY THROUGH SIMULATION OF JOB INTERVIEW. Zenodo. http://doi.org/10.5281/zenodo.442 $\underline{8778}$

Andi Asrifan, Like Raskova Octaberlina, \& Eka Safitri. (2021, January 8). THE EFFECTIVENESS OF USING RECITATIVE METHOD TO IMPROVE STUDENTS' VOCABULARY MASTERY. Zenodo. http://doi.org/10.5281/zenodo.442 8303 